Киричко Б. П., доктор ветеринарних наук, Звенігородська Т. В., аспірант*

Полтавська державна аграрна академія

\title{
ОСОБЛИВОСТІ ПАТОГЕНЕЗУ ТА ЛІКУВАННЯ ХВОРОБ ПАРОДОНТУ В ДОМАШНІХ КОТІВ
}

\section{Рецензент -доктор ветеринарних наук А. А. Замазій}

\begin{abstract}
Встановлено, щуо за хвороб пародонту реєструється підвищення показника ШОЕ, рівня глюкози та загального білку, зменшення кількості еритроциттів та лейкоцитів у крові. В ротовій рідині відмічається гіперпротеїнемія та гіперглікемія. Прослідковано залежність активності каталази та рівня малонового діальдегіду під час лікування. 3ареєстровано підвищення лізоцимної активності під час лікування в порівнянні з тваринами до лікування. Поєднання консервативного та оперативного методів лікування запальних хвороб пародонту в котів і використання імплантатів «Біомін» дають позитивний ефект.
\end{abstract}

Ключові слова: домашні коти, пародонтит, гінгівіт, лікування.

Постановка проблеми. Ветеринарна стоматологія дрібних домашніх тварин - новий і актуальний розділ у клінічній ветеринарній хірургії. Ïї актуальність обумовлена збільшенням поголів'я домашніх собак і кішок, а також збільшенням частоти появи патології зубощелепової системи. Останніми роками ветеринарна стоматологія розвивається високими темпами, що пов'язано 3 удосконаленням стоматологічної техніки і методик лікування. Проте в нашій країні дослідження в цій області мають спорадичний характер.

У клінічній практиці все більше з'являється тварин із захворюваннями, що локалізуються в ротовій порожнині. Вивчення літературних джерел із питань стоматології дрібних домашніх тварин показало, що вітчизняні дослідники приділяють мало уваги цій проблемі, а більшість інформації в цьому аспекті знаходимо у зарубіжних авторів. Вітчизняні джерела з ветеринарної стоматології дрібних домашніх тварин зводяться, головним чином, до різних повідомлень практикуючих ветеринарних лікарів, що мають науково-популярний характер [3].

Аналіз основних досліджень і публікацій, у яких започатковано розв'язання проблеми. Хвороби пародонту становлять найбільшу групу захворювань ротової порожнини в котів. Змінений тип годівлі, незбалансованість раціону, неповне самоочищення зубів і порушення правил селекційного відбору виключають із боротьби власні захисні механізми організму тварини. Карієс, пульпіт, неправильний прикус, деформація зубів, пародонтопатії завдають дискомфорту тварині, викликають ускладнення в травній, серцево-судинній та дихальній системах.

За даними австрійських вчених, захворювання пародонту реєструється в 25-50\% котів. Серед хвороб пародонту у котів найчастіше трапляються гінгівіти. На другому місці за поширеністю стоять пародонтопатії, до яких належать пародонтити різного ступеню складності та пародонтози [5-6].

Пародонтопатії реєструються переважно у тварин дорослого віку. Причини різноманітні - як місцеві, так і загальні. Генетична схильність, особливості породи та екстер'єру, порушення розвитку кістяка призводять до формування неправильного прикусу й некомплектних зубів. Це, в свою чергу, сприяє накопиченню нашарувань і зубного каменя, що $є$ одним із найважливіших патогенних чинників у розвитку пародонтопатій $[1,4]$.

Мета роботи: шляхом клінічно-експериментальних досліджень дослідити патогенез захворювань пародонту та запропонувати ефективні методи лікування.

Завдання: визначити показники ШОЕ, рівня глюкози та загального білка, кількість еритроцитів та лейкоцитів в крові, активність каталази та рівень малонового діальдегіду під час лікування.

Матеріали і методи. Матеріалом дослідження були зразки крові та ротової рідини, відібрані в котів, віком від трьох до восьми років, в яких реєстрували хвороби пародонту, та зразки крові від клінічно здорових тварин (для порівняння). Зразки крові для лабораторних досліджень відбирали до початку лікування, на 10 -у та 20-у добу після лікування. Проводили загальний аналіз крові та біохімію за стандартними методиками.

* Науковий керівник - доктор ветеринарних наук Б. П. Киричко 
Вміст малонового діальдегіду вимірювали у тесті з тіобарбітуровою кислотою за методикою Л. І. Андрєєвої та ін. Визначення активності каталази (Кат, КФ 1.11.1.6) проводили за методом М. А. Королюка і співавт. [2].

Визначення активності лізоцимної сироватки крові проводили фотоелектроколориметричним методом у модифікації відділу зоогігієни УНДІЕВ [5], а як тест-культуру використовували M. lysodeikticus (штам 2655).

Хворих тварин лікували за розробленою нами методикою.

Результати досліджень. Хворих тварин було поділено на дві групи: перша - тварини 3 ознаками гінгівіту, друга - тварини з ознаками пародонтиту. Кожну групу було розділено ще на дві підгрупи, які відрізнялися лікуванням. У тварин обох груп проводили чистку та полірування зубів за допомогою ультразвукового скелера UDS-L та портативного стоматологічного апарату БУС02. В першій групі використовували аплікації 3 маззю метилурацил + мірамістин для однієї підгрупи котів і гель «Зубастик» - для другої. Дру- гій групі був проведений закритий та відкритий кюретаж (у залежності від ступеню захворювання) та, в окремих випадках, використано імплантати 3 керамічного гідроксилапатиту й трикальційфосфату «Біомін» [2, 6]. Після оперативного втручання призначали антибіотикотерапію, введення в раціон вітамінів «Фітоміни для зубів і форм скелета для кішок» та аплікації. Тваринам обох груп застосовували препарат «Румосол», що має антиоксидантну, імуностимулюючу, гепатопротекторну та ранозагоюючу дії. Результати змін показників у крові та ротовій рідині після лікування наведено в таблиці.

Дослідженнями морфологічного складу крові в котів 3 ознаками гінгівіту та пародонтиту до лікування встановлено зменшення кількості еритроцитів, збільшення показника ШОЕ, гіперглікемію та гіперпротеїнемію. Збільшення рівня глюкози та вмісту загального білка реєстрували також і в ротовій рідині. За пародонтиту відмічали лейкоцитопенію та нейтрофільоз зі зсувом ядра вправо, що вказує на хронічну запальну реакцію в організмі тварин. Дослідженнями

Деякі показники крові та ротової рідини за лікування запальних хвороб пародонту, $\mathrm{M \pm m}$

\begin{tabular}{|c|c|c|c|c|c|}
\hline \multirow{2}{*}{ Показник } & \multirow{2}{*}{$\begin{array}{c}\text { Клінічно } \\
\text { здорові тва- } \\
\text { рини }(\mathrm{n}=3)\end{array}$} & \multirow{2}{*}{$\begin{array}{l}\text { Групи } \\
\text { тварин }\end{array}$} & \multirow{2}{*}{$\begin{array}{c}\text { Перед } \\
\text { лікуванням }\end{array}$} & \multicolumn{2}{|c|}{ Період дослідження, доба } \\
\hline & & & & 10 & 20 \\
\hline \multirow{2}{*}{ Еритроцити, Т/л } & \multirow{2}{*}{$6,0 \pm 0,2$} & 1 & $4,8 \pm 0,5$ & $5,5 \pm 0,5$ & $6,8 \pm 0,7^{*}$ \\
\hline & & 2 & $3,3 \pm 0,41^{\circ}$ & $4,2 \pm 0,23$ & $5,7 \pm 0,3 * * *$ \\
\hline \multirow{2}{*}{ Лейкоцити, Г/л } & \multirow{2}{*}{$9,3 \pm 1,1$} & 1 & $10,4 \pm 1,02$ & $11 \pm 0,64$ & $10,4 \pm 0,8$ \\
\hline & & 2 & $5,2 \pm 0,7^{\circ}$ & $7,4 \pm 0,52$ & $8,2 \pm 1,03$ \\
\hline \multirow{2}{*}{ ШОЕ, мм/год. } & \multirow{2}{*}{$3,75 \pm 0,52$} & 1 & $5,2 \pm 1,8$ & $4,2 \pm 0,84$ & $3,7 \pm 0,53$ \\
\hline & & 2 & $16,5 \pm 5,2^{\circ}$ & $10,3 \pm 2,1$ & $4,3 \pm 0,9 *$ \\
\hline \multirow{2}{*}{$\begin{array}{c}\text { Загальний білок } \\
\text { (у сироватці крові), г/л }\end{array}$} & \multirow{2}{*}{$55,4 \pm 4,11$} & 1 & $71,42 \pm 3,6^{\circ}$ & $59,6 \pm 4,2 *$ & $49,5 \pm 2,1 * * *$ \\
\hline & & 2 & $74,5 \pm 4^{\circ}$ & $60,7 \pm 4 *$ & $58 \pm 3^{* *}$ \\
\hline \multirow{2}{*}{$\begin{array}{c}\text { Загальний білок } \\
\text { (у ротовій рідині), г/л }\end{array}$} & \multirow{2}{*}{$11,3 \pm 0,51$} & 1 & $20,3 \pm 2,4^{*}$ & $15,6 \pm 2,2$ & $10,5 \pm 0,8^{* *}$ \\
\hline & & 2 & $17,6 \pm 1,7^{\circ}$ & $16,4 \pm 1,84$ & $12 \pm 1,2 *$ \\
\hline \multirow{2}{*}{ Каталаза, мккат/л } & \multirow{2}{*}{$594,0 \pm 18,0$} & 1 & $519 \pm 53$ & $656,2 \pm 13^{*}$ & $601,5 \pm 27,3 * *$ \\
\hline & & 2 & $545 \pm 11,4^{\circ}$ & $699 \pm 15,3 * * *$ & $618 \pm 14,2 * * *$ \\
\hline \multirow{2}{*}{$\begin{array}{c}\text { Малоновий діальдегід, } \\
\text { мкмоль/л }\end{array}$} & \multirow{2}{*}{$3,45 \pm 0,7$} & 1 & $4,8 \pm 0,6$ & $4,5 \pm 0,9$ & $3,32 \pm 0,3^{*}$ \\
\hline & & 2 & $4,62 \pm 0,3$ & $3,61 \pm 0,3^{*}$ & $3,12 \pm 0,6^{*}$ \\
\hline \multirow{2}{*}{$\begin{array}{l}\text { Лізоцимна активність } \\
\text { (у сироватці крові), \% }\end{array}$} & \multirow{2}{*}{$18,0 \pm 0,53$} & 1 & $4,8 \pm 0,9^{\cdots}$ & $5,6 \pm 1,1$ & $7,8 \pm 0,8 *$ \\
\hline & & 2 & $5,5 \pm 0,72^{\cdots}$ & $6,2 \pm 1,23$ & $6,85 \pm 0,78$ \\
\hline \multirow{2}{*}{$\begin{array}{l}\text { Лізоцимна активність } \\
\text { (у ротовій рідині), \% }\end{array}$} & \multirow{2}{*}{$53,0 \pm 3,1$} & 1 & $47,5 \pm 2,3$ & $43,1 \pm 1,8$ & $40,3 \pm 1,52 *$ \\
\hline & & 2 & $35,4 \pm 1,2^{\cdots}$ & $40,2 \pm 2$ & $40,6 \pm 1,8^{*}$ \\
\hline \multirow{2}{*}{$\begin{array}{c}\text { Глюкоза } \\
\text { (у сироватці крові), } \\
\text { ммоль/л }\end{array}$} & \multirow[b]{2}{*}{$4,7 \pm 0,03$} & 1 & $5,42 \pm 0,04 \cdots$ & $4,91 \pm 0,1 * * *$ & $4,6 \pm 0,03 * * *$ \\
\hline & & 2 & $9,2 \pm 0,04^{\cdots}$ & $7,46 \pm 0,05 * * *$ & $6,53 \pm 0,03 * * *$ \\
\hline \multirow{2}{*}{$\begin{array}{c}\text { Глюкоза } \\
\text { (в ротовій рідині), ммоль/л }\end{array}$} & \multirow{2}{*}{$1,02 \pm 0,4$} & 1 & $3,65 \pm 0,5^{\circ}$ & $2,4 \pm 0,04^{*}$ & $1,1 \pm 0,3 * * *$ \\
\hline & & 2 & $4,1 \pm 0,4^{\cdots}$ & $3,5 \pm 0,2$ & $2,75 \pm 0,4^{*}$ \\
\hline
\end{tabular}

Примітка: * - $\mathrm{P}<0,05, * *-\mathrm{P}<0,01, * * *-\mathrm{P}<0,001$ порівняно 3 показниками до лікування; - $-\mathrm{P}<0,05,{ }^{\cdots}-\mathrm{P}<0,01, \cdots-\mathrm{P}<0,001$ порівняно з клінічно здоровими тваринами 
динаміки окремих показників пероксидного окиснення ліпідів та антиоксидантного захисту було встановлено, що за хвороб пародонту в крові котів знижується активність каталази й підвищується рівень малонового діальдегіду, в порівнянні $з$ клінічно здоровими котами. Причиною цього може бути порушення трофіки тканин ротової порожнини, наявність патогенної мікрофлори, тканинна гіпоксія. Під час лікування на 10-у й 20-у добу було відмічено підвищення активності каталази ( $\mathrm{P}<0,05$ - при гінгівіті та $\mathrm{P}<0,001$ - при пародонтиті) та зменшення рівня малонового діальдегіду $(\mathrm{P}<0,05)$. Рівень глюкози й білків зменшився як у крові, так і в ротовій рідині.

Значну роль у виникненні та хронічному перебізі запальних хвороб пародонту займають фактори місцевого неспецифічного захисту, так як від них, певною мірою, залежить здатність організму протистояти на початку інфекційного процесу. Як видно з таблиці, за хвороб пародонту відмічається зниження рівня лізоцимної активності як у сироватці крові, так і в ротовій рідині. У процесі лікування на $10-$ у та $20-$ у добу рівень лізоцимної активності залишався низьким у порівнянні з клінічно здоровими тваринами. Од-

\section{БІБЛІОГРАФІЯ}

1. Васильева М. Б. Воспалительные заболевания пародонта у собак : дис. ... канд. вет. наук: спец. 16.00.05 «Ветеринарная хирургия»/ М. Б. Васильева. - Санкт-Петербург, 2009. - С. 71-101.

2. Дослідження пероксидазної оксидації ліпідів та антиоксидантного захисту організму в клінічній практиці: методичні рекомендації / Кочаровський Б. В., Новак В. Л., Руденко В. П. [та ін.] Львів, 2002. - 20 с.

3. Карпович E. A. Клинико-рентгенографическая диагностика и оперативное лечение пульпита коренных зубов у собак: авт. дис. канд. вет. наук: спец. 16.00.05 «Ветеринарная хирургия» / нак слід відзначити, що в сироватці крові у тварин першої та другої груп у ході лікування відмічається тенденція до підвищення активності лізоциму, порівняно 3 даними до лікування (5,6 $\pm 1,1$ на 20-у в порівнянні $34,8 \pm 0,9$ при гінгівітах і $6,85 \pm 0,78$ на 20 -у в порівнянні з $5,5 \pm 072$ при пародонтитах). Це може свідчити про активацію неспецифічного захисту.

Висновки: 1. За хвороб пародонту реєструється підвищення показника ШОЕ, рівня глюкози та вмісту загального білка, зменшення кількості еритроцитів і лейкоцитів у крові. В ротовій рідині відмічається гіперпротеїнемія та гіперглікемія.

2. До лікування відмічалося зниження активності каталази й підвищення рівня малонового діальдегіду, під час лікування реєструвалося достовірне підвищення активності каталази та зниження рівня малонового діальдегіду, що вказує на ефективність лікування.

3. Під час лікування зареєстровано тенденцію до підвищення активності лізоциму, в порівнянні 3 клінічно здоровими котами, що може свідчити про активацію неспецифічного імунітету.

Е. А. Карпович. - М., 2010. - 18 с.

4. Орехова Л. Ю. Заболевания пародонта. / Л. Ю. Орехова. - М. : Полимедиапресс, 2004. C. 107-140.

5. Чумаченко B. E. Методические рекомендации по определению естественной резистентности у сельскохозяйственных животных для ветеринарных специалистов / Чумаченко В. Е., Сичкарь В. С., Оленич Ю. В. - К. : УСХА, 1992. - 46 р.

6. Periodontal Surgery: A Clinical Atlas / Naoshi Sato / Yuzava, Japan, 2000. - 447 p. 